\title{
Leading Product Development of Fruits Using Location Quotient InTuban Regency
}

\author{
Kristiawan $^{1}$., N. Hanani AR $^{2}$.,Soemarno ${ }^{3}$., and S. Y. Tyasmoro ${ }^{4}$ \\ ${ }^{1}$ Doctoral Program in Environmental Sciences and Development, University of Brawijaya, Malang, Indonesia; \\ ${ }^{2}$ Department of Social Economics, Faculty of Agriculture, University of Brawijaya, Malang, Indonesia \\ ${ }^{3}$ Department of Soil Science, Faculty of Agriculture, University of Brawijaya, Malang, Indonesia. \\ ${ }^{4}$ Department of Environmental Resources, Faculty of Agriculture, University of Brawijaya, Malang, Indonesia.
}

\begin{abstract}
Tuban has a major problem in the development of superior products of fruits is the absence of scientifically superior product descriptions both quantitatively and qualitatively. Please also note any factors that encourage and inhibit the development potential of the excellent products of the fruit. The purpose of research for a description of the potential fruits of superior products using the Location Quotient (LQ) in Tuban and the factors that drive and inhibit the development of superior product potential fruits. The study was conducted in January and April 2016. The results showed that the featured product Tuban fruits are mango, star fruit, sapodilla, guava, guava and jackfruit. $L Q$ value of the fruit is greater than 1 , or a commodity basis. The fruits are not a commodity base with $L Q$ values smaller than 1 are melon, watermelon, citrus, Duku, oranges, papaya, bananas and avocados. Factors that encourage the development of superior products is the uniqueness or distinctiveness taste of fruit, land and agro-climatic suitability, pretty good road infrastructure in all regency, the government's support in the regulation of agriculture, their marketing opportunities are quite extensive, regional and national scale. While the factors inhibiting the development of superior products is the lack of creative effort in marketing the products featured, low agricultural practices good (good agricultural practice), weak capitalization farmers, yet implementation of the principles of organic farming, and is still a lack of facilities and infrastructure of post-harvest and processing activities agriculture, particularly fruit. Recommendation is the establishment of institutional marketing, such as marketing associations fruits by farmer groups, support or facilitation SKPD to carry out the development of superior products fruits, in terms of providing the marketing infrastructure in the form of a means of processing the fruits and the central marketing of fruits in Tuban, required an increase in promotion and investment in the development of superior products fruits undertaken by farmer groups in collaboration with the government and employers Tubanfruits.
\end{abstract}

Keywords: fruits, location quotient, superior products

\section{Introduction}

Agricultural commodities in the GDP structure a considerable contribution to the economy in Tuban. Agricultural commodities that include food crops, plantations, forestry, fisheries and farms have the potential and problems vary. Horticulture grew at an average of $2.99 \%$ over the last 5 years. Agriculture, forestry and fisheries contribute economic value by an average of $20.03 \%$ of the GDP of Tuban. Horticultural crops subsector only contributes to the economic value of $0.51 \%$ of total GDP. The largest contribution in the agricultural sector is derived from food crops (rice and pulses), amounting to 8.27\% of the GDP. Determination superior product derived from the theory of economic growth, namely Theory Basis. Economic base theory states that the main determinants of economic growth of a region are directly related to the demand for goods and services from outside the area. The growth of industries that utilize local resources, including labor force and raw materials for export, will generate local wealth and employment creation.

Regional development strategy that appeared to be based on this theory is the emphasis on the importance of aid to businesses that have a market both nationally and internationally. Implementation of policies includes the reduction of barriers / constraints on firms existing export-oriented and will be erected in the area (Arsyad, 2002). This study aims to determine the potential for superior product descriptions fruits using Location Quotient (LQ) in Tuban and the factors that encourage and inhibit the development potential of the excellent products of the fruit. Benefits of the research is to be a scientific reference as a primary consideration for local governments in policy formulation and planning of agricultural development, in particular to develop production and value-added products featured fruit, improving the welfare of farmers and regional economic growth.

\section{Basic Theory}

The flagship product is a commodity that adds value and highest revenue contribution to a region's economy. This opinion is based on aspects of the value and contribution of a commodity / product. Products that 
provide the highest added value throughout the value chain and provide the largest contribution of a regional economy is a superior product. So as to find a product that adds value then needs to be analyzed with two approaches, industrial tree approach and the value chain (value chain). According to Eko Sri (2010), the notion of a commodity is a product produced continuously by a manufacturer. Commodity featured say if a big contribution minimum for the producers themselves, based on certain criteria. Criteria commodity regarded as a commodity, which is an added value sufficiently greater than the total output is above average value added across activities of the regional economy, the content of domestic input is quite large, specialized export interprovincial and national quite large, the establishment of industrial investment commodity is adequate large, index spread (forward and backward linkage) of the more than 1, which is a reference to the front or uptake of the output, and contribute to the economy (GDP), high enough above the average across the business role of the regional economy.

Criteria superior products should also refer to the Minister of Agriculture No. 76 of 2012, which states that the limitation flagship product horticultural product is competitive, market-oriented and environmentally friendly, as well as providing a high economic value if developed optimally to meet the needs of the market in domestic and/or export. Other things to consider from a superior product is to consider the amount of absorption of labor, the industry is relatively safe for the environment, the provision of pressure (weight) different on each criterion seed, even if necessary, phasing weights for some period of time or certain achievements. The main problems faced Tuban in the development of superior products of fruits is the absence of scientifically superior product descriptions both quantitatively and qualitatively. Please also note any factors that encourage and inhibit the development potential of the excellent products of the fruit.

\section{Material and Methods}

The research location in Tuban, in 20 districts. As the sample were selected 10 districts centers of production of fruits as samples in this activity. Among other districts that elected District of Soko, Grabagan, Semanding, Plumpang, Cross, Tambakboyo, Bancar, Bangilan, Kenduruan and Singgahan. Ten (10) districts are chosen each of the 3 villages, and each village selected two farmers as respondents. The number of respondents 60 people, chosen by purposive random sampling method. The research activities include product assessment base and non-base, farm analysis and assessment of the factors driving and inhibiting product of superior fruit. The analysis used in this study is Location Quotient (LQ) and SWOT analysis.

Analysis of each sub-district horticultural commodity in Tuban with calculation Location Quotient (LQ) using the following formula (Hendayana, 2003):

$$
L Q=\frac{X_{r} / R V_{r}}{X_{n} / R V_{n}}
$$

Dimana :

$L Q \quad=$ Location Quotient value of commodity $i$

$\mathrm{Xr} \quad=i$ value commodity production at district level

$\mathrm{RVr} \quad=$ the total value of production of agricultural commodities at district level

$X n \quad=i$ value commodity production at district level

$R V n \quad=$ the total value of agricultural production at the district level

Measurement criteria of value if the LQ LQ ie $\geq 1$, means commodity $i$ is a commodity basis. Whereas if LQ $<1$, meaning i mean commodity is a commodity non bases. In relation to the research conducted, if the value of $L Q \geq 1$ then the commodities are in Tuban is a commodity (a commodity basis) and the potential to be developed as a driver of the economy in Tuban. If the value of LQ $<1$ then the commodity is not a commodity and less potential to be developed as a driver of the economy in Tuban. In addition to determining fruit commodity based LQ, the benefits of these commodities also analyzed based on the level of conformity agroekologisnya.

\subsection{Production of Fruit Tuban}

\section{Result and Discussion}

The production of fruits in Tuban, including fruits seasonal and yearly. Based on data from the Department of Agriculture Tuban 2015, this type of seasonal fruits is cantaloupe, watermelon, and cantaloupe. While the annual fruit is avocado, star fruit, duku/tan, durian, guava, guava, citrus, grapefruit, mango, mangos teen, jackfruit, pineapple, papaya, banana, rambutan, sour sop, sapodilla, passion fruit, bark, breadfruit, apples and grapes. Melon, watermelon and cantaloupe grown every year by farmers to meet market demand for climate and suitable land and provide farm income is relatively high compared to other annual crops. The area of harvesting fruit this season fluctuates with commodity prices in the market. The tendency of seasonal fruit harvest area has declined when compared between the areas harvested in 2011 until 2015. 
Annual fruit in general is a garden plant and crops are not cultivated commercially by farmers. Except for the star fruit, guava, citrus, papaya and banana.

Table 1.Distribution GRDP Tuban ADHB by Industrial Origin, 2011-2014 (\%)

\begin{tabular}{|c|l|c|c|c|c|}
\hline No. & \multicolumn{1}{|c|}{ Business field } & 2011 & 2012 & 2013 & 2014 \\
\hline & Agriculture sector & 19,22 & 20,29 & 20,65 & 20,95 \\
\hline 1. & Crops & 8,23 & 8,33 & 8,22 & 8,27 \\
\hline 3. & Horticulture & 0,54 & 0,50 & 0,48 & 0,51 \\
\hline 4. & Plantation & 1,00 & 1,03 & 1,00 & 1,02 \\
\hline 5. & Livestock & 3,58 & 3,66 & 3,66 & 3,66 \\
\hline 6. & Agricultural services and Hunting & 0,17 & 0,17 & 0,17 & 0,18 \\
\hline 7. & Forestry and Logging & 1,75 & 2,42 & 2,48 & 2,56 \\
\hline 8. & Fishery & 3,95 & 4,18 & 4,59 & 4,77 \\
\hline & Non-Agricultural Sector & 80,78 & 80,71 & 80,35 & 80,05 \\
\hline & GRDP Tuban & 100 & 100 & 100 & 100 \\
\hline
\end{tabular}

Source: Processed Data, 2016

Star fruit is one of the flagship products that have been set by the central government, which is known as BelimbingTasikmadu. Development of red guava fruit increased due to high demand in the markets of the major cities in East Java. While the development of citrus still not give a satisfactory result farmers. The main markets of fruits Tuban is KramatJati wholesale market in Jakarta, markets in Rembang in Central Java and other major cities in East Java, such as Surabaya and Malang. Fruits marketed in fresh form through wholesalers located in Tuban. There are no processed fruit products in Tuban prominent enough to be featured product.

\subsection{Determination of Fishery Products of the LQ method}

Every agricultural commodities potentially superior product has two important characteristics, namely: economic value contributed greatly to the GDP growth as a whole and has a greater economic value than the average growth of the sector in the GDP. Commodity fruits included in the field of horticulture business, its contribution are very small compared to other commodities. This analysis limits the determination of excellent products within the scope of horticulture course. Fruits in horticulture are a kind of commodity greatest contribution. In addition to fruits, including horticulture commodities that are plant vegetables, flowers and medicinal plants / bio.

His analysis using Location Quotient (LQ). This method uses the broad parameters of the harvest and production of fruits of seasonal and annual as the numbers approach (proxy). If the value of LQ> 1 then the commodity is a commodity basis or featured and if the value of LQ $<1$ then the commodity is not a commodity basis or unseeded. For the annual fruit crop Tuban LQ analysis results as follows:

Table 2.Featured products Fruits Year Tuban based Value LQ

\begin{tabular}{|c|c|c|c|c|}
\hline No. & Commodity & LQ & Status & Superior \\
\hline 1. & Manggo & 2,043 & Base & Yes \\
\hline 2. & Belimbing & 3,138 & Base & Yes \\
\hline 3. & Sapodilla & 13,319 & Base & Yes \\
\hline 4. & Jackfruit & 2,957 & Base & Yes \\
\hline 5. & Guava & 1,376 & Base & Yes \\
\hline 6. & Water apple & 1,728 & Base & Yes \\
\hline 7. & Tangerine & 0,005 & Non Base & No \\
\hline 8. & DukuPrunggahan & 0,143 & Non Base & No \\
\hline 9. & Papaya & 0,229 & Non Base & No \\
\hline 10. & Banana & 0,586 & Non Base & No \\
\hline 11. & Avocado & 0,002 & Non Base & No \\
\hline
\end{tabular}

Source: Processed Data, 2016.

As for fruit plants annuals, LQ analysis results as follows:

Table 3.Featured products Fruits Annuals Tuban based Value LQ

\begin{tabular}{|c|l|c|c|c|}
\hline No & Commodity & LQ & Status & Superior \\
\hline 1 & Cantaloupe & 1,40 & Base & Yes \\
\hline 2 & Melon & 0,79 & Non Base & No \\
\hline 3 & Watermelon & 0,32 & Non Base & No \\
\hline
\end{tabular}

Sumber: Data Diolah, 2016.

\subsection{Incentives and Featured Products}

SWOT analysis is used to assess quantitatively the factors that encourage and inhibit the development of superior products fruits in Tuban. Based on the analysis, strengths and opportunities made indicator for factors that promote the development of superior products fruits. Aspects of the power of agribusiness fruits 
Tuban include: (1) unique or characteristic of the product, (2) the suitability of agro-climate plants, (3) the carrying capacity of the land for the extension or expansion of planting area, (4) the road infrastructure of production is quite good, and (5) institutional support strong farming. Aspects opportunities agribusiness fruits Tuban include: (1) the existence of government policy support, the district, provincial and national levels, (2) the distribution agreement between farmer groups and traders at the national level, (3) the existence of domestic demand and increasing exports, (4) support the promotion and exhibition facilities of the regional government and the province of East Java.

While the weakness and the threat used as factors that hinder the development of superior products. Aspects of weakness agribusiness fruits Tuban include: (1) skill cultivation technology the farmer still needs to be improved according to the principles Practice Good agricultural (Good Agricultural Practice), (2) weak capitalization farmers to increase the productivity of farming, (3) lack the means and infrastructure for postharvest and processing of fruits at the level of farmers' groups, (4) not applying the principles of sustainable or organic farming, and (5) the absence of support from research institutions for the development of superior products fruits Tuban. Aspects threat to agribusiness fruits Tuban include: (1) the existence of competition fruit from outside the area, especially for fruits annuals, (2) the effects of changes in the uncertain climate due to global warming, (3) the decrease in fertility of agricultural land, due to the use of chemical fertilizers in the long term, (4) the declining national and global economic growth. Furthermore, through a quantitative SWOT analysis can be seen that the development of superior products Tuban fruits is in quadrant aggressive. This means that the production and marketing of fruits Tuban they can be grown even better in the future. His strategy was to maximize the strengths and opportunities that exist. Especially characteristic of fruits and availability of existing land. The main priority development Tuban fruits are mango, star fruit and guava.

\section{Conclusions and Recommendations}

Based on the results and discussion we concluded that the increase in production of fruits in Tuban can be done by increasing productivity per unit of hectare corresponding ordinances good farming and expand the planting area, fruit products flagship annual Tuban include mango, starfruit, guava beans, guava, sapodilla, and jackfruit. While seasonal fruits superior is cantaloupe. Melon and watermelon can be seeded if able to expand the cropping area and get a stable price in the market of agricultural products. In addition, the main driving factors behind the development of superior products fruits Tuban is the unique taste of the fruit, agro-climatic suitability and sufficient land capacity. While uamanya inhibiting factor is the skill of farmers cultivating fruits that are still weak, the lack of farm capital, and the lack of post-harvest facilities and processing of fruits.

Recommendations based on the results of this study, among others, is necessary to the establishment of the marketing agency in the form of an association of producers of fruits so as to increase the volume and scope of the market for superior products, fruit processing seed to increase the added value of agricultural products and increase farmers' income, and provide training intensive regarding good cultivation techniques according to the principles of good agricultural practices, sustainable or environmentally friendly as well as expected this study can be continued in a comprehensive manner across the district to determine the priority areas in the government's policy in the field of production and processing of fruits featured.

\section{References}

[1]. Anonim, 2014. Minister Regulation No. 9 of 2014 on Guidelines for Superior Product Development Regions. Jakarta.

[2]. Anonimus, 2012. Regulation of the Minister of Agriculture No. 76 / Permentan / OT.140 / 12/2012 About Terms and Procedures for Determination of Products of Horticulture. Ministry of Agriculture. Jakarta.

[3]. Arsyad, L. 2002. Introduction of Regional Economic Planning (second edition). Yogyakarta: BPFE. UGM. Yogyakarta.

[4]. The Central Bureau of Statistics, 2014. Tuban in Figures 2014, Central Bureau of Statistics Tuban. Tuban.

[5]. The Central Bureau of Statistics, 2015. Tuban in Figures 2015. Statistics Agency Tuban. Tuban.

[6]. Planning and Regional Development Tuban, 2014. Potential and Superior Products Tuban. Tuban.

[7]. The Central Statistics Agency of East Java, 2014. The East Java Provincial Agriculture Indicators 2014. Surabaya.

[8]. The Central Statistics Agency of East Java, 2015. Gross Regional Domestic Product (GRDP) Regency / City by Industrial 20102014 Surabaya.

[9]. Eko Sri Meiningsih, 2010. Analysis of Agricultural Sector Commodity Sukoharjo Before And During Autonomy. Graduate Thesis. Master of Economics and Development Studies. UNS. Surakarta.

[10]. Hendayana, R. 2003. Application Method Location Quotient (LQ) in the determination of the National Commodities. Agricultural Informatics. Volume 12, 2003. 